\title{
Aktivitas Antihipertensi Ekstrak dan Fraksi-Fraksi Daun Avokad (Persea americana Mill) pada Tikus Jantan dengan Parameter Sistolik dan Diastolik
}

\author{
Novi Elisa ${ }^{1)}$, Aloysius Barry Anggoro ${ }^{1)}$, Erwin Indriyanti ${ }^{1)}$ \\ ${ }^{1)}$ Sekolah Tinggi Ilmu Farmasi Yayasan Pharmasi Semarang \\ novieliza737@gmail.com
}

\begin{abstract}
ABSTRAK
Penyakit kardiovaskuler yang terjadi di Indonesia berawal dari penyakit menular kemudian beralih menjadi tidak menular, salah satunya hipertensi. Tujuan dari penelitian ini untuk mengetahui skrining fitokimia dan hasil uji KLT ekstrak dan fraksi-farksi daun avokad pada tikus jantan yang dibuat model hipertensi dengan induksi $\mathrm{NaCl}$ dan prednison. Pengujian ini dilakukan selama 28 hari menggunakan alat Blood Presure Analizer Tail Caff dengan kelompok perlakuan kontrol normal, positif, negatif, ekstrak dosis $75 \mathrm{mg} / \mathrm{kgbb}, 150 \mathrm{mg} / \mathrm{kgbb}, 250 \mathrm{mg} / \mathrm{kgbb}$ dan fraksi air, etil asetat, n-heksana masing-masing kelompok berisi 5 ekor tikus. Pengukuran tekanan darah dilakukan pada T0 (belum diberi perlakuan), T1, T2, T3 (induksi NaCl dan Prednison), T4 (diberikan dosis ekstrak dan dosis fraksi). Hasil uji skrinning fitokimia positif flavonoid dan uji KLT dimana nilai Rf yang dihasilkan setelah percobaan KLT dengan metode penyinaran UV 254, ekstrak daun alpukat dengan menggunakan baku kuersetin yang dihasilkan Rf 0,75 , fraksi air 0,82 , n-heksana 0,93 , etil asetat 0,82 dari hasil tersebut dapat dibuktikan terjadi penurunan aktivitas tekanan darah. Hasil persentasi penurunan ekstrak dan fraksi-fraksi daun alpukat menunjukkan dosis efektif ekstrak $250 \mathrm{mg} / \mathrm{kgbb}$ yaitu 5,87/10,96\% sig > 0,05 berbeda makna dengan kelompok negatif dan fraksi etil asetat 5.71/14.53\%. sig > 0,05 berbeda makna dengan kelompok negatif.
\end{abstract}

Kata kunci: Antihipertensi; daun avokad; diastolik; sistolik; tikus

\section{Anti-Hypertension Activity of Avocado (Persea americana Mill) Leaves Extracts and Fractions in Male Rats with Systolic and Diastolic Parameters}

\begin{abstract}
One of cardiovascular diseases that occur in Indonesia that start from infectious diseases and then turn into non-infectious diseases is hypertension. This study aimed to determine the phytochemical screening and TLC test results of avocado leaves extract and fractions in hypertension-modeled male rats through induction of $\mathrm{NaCl}$ and prednisone. This test was done in 28 days used Blood Pressure Analyzer Tail Caff with normal, positive, negative control treatment groups, extract doses of $75 \mathrm{mg} / \mathrm{kgbb}, 150 \mathrm{mg} / \mathrm{kgbb}, 250 \mathrm{mg} / \mathrm{kgbb}$ and water, ethyl acetate, n-hexane fractions for each group. Each group contains 5 rats. Blood pressure measurement was done at T0 (untreated), T1, T2, $\mathrm{T} 3$ (induction of $\mathrm{NaCl}$ and Prednisone), T4 (given extract dose and fraction dose). The results of phytochemical screening test were positive for flavonoids and the TLC test, where the Rf value produced for avocado leaves extract after TLC test with UV 254 irradiation method, using quercetin standard produced was 0.75 , water fraction was 0.82 , n-hexane was 0.93 , ethyl acetate was 0.82 . These results then proved with decrease in blood pressure activity. The results of decreases in percentage of avocado leaves extract and fractions showed that the effective dose of extract $250 \mathrm{mg} / \mathrm{kgBW}$ was $5.87 / 10,96 \% \mathrm{sig}>0.05$, which was significantly different from negative group and ethyl acetate fraction was $5.71 / 14.53 \%$. sig $>0.05$ significantly different with negative group.
\end{abstract}

Keywords: Antihypertensive; avocado leaves; diastolic; rat; systolic

(Article History: Received 19-08-2021; Accepted 01-10-2021; Published 07-10-2021)

\section{PENDAHULUAN}

Meluasnya penyakit kardiovaskuler
yang terjadi di Indonesia berawal dari
penyakit menular yang semula menjadi dasar
pertama kemudian beralih menjadi tidak

menular (Kemenkes RI, 2014). Penyakit kardiovaskuler salah satunya adalah hipertensi. Penyakit hipertensi dibedakan menjadi dua jenis yaitu hipertensi primer dan sekunder (Mancia et al., 2013). 
Faktor-farktor yang berperan pada penyakit kardiovaskuler hipertensi yang mengarah berdasarkan epidemiologi adalah stroke, gagal jantung, infark miokard, atrial fibrilasi, diseksi aorta, dan penyakit arteri perifer berkaitan secara langsung dengan derajat peningkatan tekanan darah hipertensi ringan 140/90 mmHg (Mancia et al., 2013).

World Health Organization (WHO), 2012 menjelaskan hipertensi dapat ningkatkan kematian hamper 9,4 juta yang disebabkan bertambahnya penyakit kardiovaskuler tiap tahun ke tahun adanya hal tersebut dapat pula meningkatkan resiko kematian jantung coroner $12 \%$, stroke $24 \%$, WHO telah menyebut negara ekonomi berkembang yang mengalami penyakit hipertensi, negara maju $35 \%$. Asia Tenggara $36 \%$ orang dewasa yang mengalami hipertensi dan telah meninggal 1,5 juta disetiap tahunnya (DINKES Sulut, 2016).

Pengguanakan obat sintetik untuk penyakit hipertensi seperti captopril memiliki mekanisme kerja menghambat Angiotensin Converting Enzym (ACE), mekanisme ACEI dengan menghambat angiotensin I menjadi angiotensin II dimana sifat kerja dari angiotensin II sebagai vasokonstriktor dan berpotensi juga dalam merangsang sekresi aldosterone dimana ACEI akan memblok degradasi bradikinin dan merangsang sintesa zat-zat vasodilatasi, prostaglandin E2 dan prostasiklin (DEPKES, 2006).

Terjadi peningkatan bradikinin akan meningkatkan efek penurunan tekanan darah oleh ACEI yang bertanggung jawab juga pada efek samping batuk kering secara efektif akan mencegah dan meregresi hipertrofi vertikel kiri dengan megurangi rangsangan langsung oleh angiotensin II pada sel miokardial (DEPKES, 2006).

Adapun solusi pada pengobatan hipertensi selain dari pengguanaan obat sintetik masyarakat umum telah membudidayakan pengobatan tradisional berdasarkan ramuan nenek moyang pada jaman dahulu dengan pengobatan menggunakan tanaman-tanaman yang ada di masyarakat pada umumnya (Mardiyaningsih \& Ismiyati, 2014).

Potensi daun avokad cukup banyak dikenal pada masyarakat luas sebagai tanaman buah, perasa dan obar-obatan herba. Penggunaan daun avokad sudah banyak dilakukan masyarakat sejak zaman dulu, penggunaan daun avobat sebagai bahan obat alternatif pengganti obat hipertensi yang relatif mahal dan penggunaan harus di lakukan seumur hidup oleh penderita hipertensi (Setyawan, 2018).

Salah satu tanaman yang memiliki efek dalam menurunkan tekanan darah adalah daun avokad (Persea americana Mill) berdasarkan pengobatan tradisional, sebanyak rebusan tujuh lember daun. Tetapi pada jaman dahulu belum pernah dilakukan lebih lanjut tentang senyawa kimia yang berperan sebagai pengobatan.Sehingga dunia modern meneliti lebih lanjut senyawa-senyawa yang berperan dalam pengobatan hipertensi yaitu flavonoid, saponin dan tanin (Mardiyaningsih \& Ismiyati, 2014).

Menurut penelitian Bernes Griner McFann dan Nahin tahun 2002 di Amerika, menyatakan ada beberapa faktor yang mendorong masyarakat memilih Complementary and Alternative Medicine (CAM) masyarakat meyakini apabila kombinasi pengobatan medis konvensional akan lebih membantu dalam penyembuhan $(54,9 \%)$ adanya ketertarikan ingin mencoba, $(50,1 \%)$ karena provisional pengobatan konvensional menyarankan untuk mencoba (26\%) DAN (13\%) pengguna yang mengakatan obat medis konvensional mahal (Barnes et al., 2008).

Penelitian ini memiliki tujuan untuk mengetahui skrining fitokimia dan hasil uji KLT ekstrak dan fraksi-farksi daun avokad pada tikus jantan yang dibuat model hipertensi dengan induksi $\mathrm{NaCl}$ dan prednison. Pengujian ini dilakukan selama 28 hari menggunakan alat MrBP Analizer Tail Caff dengan kelompok perlakuan kontrol normal, positif, negatif, ekstrak dosis $75 \mathrm{mg} / \mathrm{kgbb}$, $150 \mathrm{mg} / \mathrm{kgbb}, 250 \mathrm{mg} / \mathrm{kgbb}$ dan fraksi air, etil asetat, n-heksana masing-masing kelompok berisi 5 ekor tikus.

\section{METODE PENELITIAN}

Penelitian eksperimental yang dilaksanakan pada bulan Maret 2021 sampai Agustus 2021 yang dilakukan di Laboratorium Sekolah Tinggi Ilmu Farmasi Yayasan Pharmasi Semarang dan Patologi Anatomi Universitas Gadjah Mada Yogyakarta.

Penelitian ini sudah mendapat persetujuan etik dengn nomor 263/AHWSW/KEPK/STIFAR/EC/V/2021(Mardiyaningsih \& Ismiyati, 2014). 


\section{Determinasi Tanaman}

Determinasi tanaman dilakukan di Laboratorium Biologi Farmasi Sekolah Tinggi Ilmu Farmasi Yayasan Pharmasi Semarang. Dengan menggunakan tanaman daun avokad meliputi (daun, akar, batang, biji).

Hasil determinasi menyatakan spesies tumbuhan merupakan tanaman Persea americana Mill yang merujuk pada sitasi (Soemarie et al., 2016).

\section{Alat}

Ekstrak dan fraksi yaitu kain flannel, kertas saring whatman, bejana bewarna gelap, neraca elektrik, beaker glass, oven, blender, ayakan dan vakum, batang pengaduk, Rotary Evaporator, alat untuk perlakuan hewan uji adalah timbagan analitik, alat untuk mengukur tekanan darah alat @ Instrumen MrBp analyzer tail cuff. Alat untuk penetapan susut pengeringan moisture balance, lempeng KLT.

\section{Bahan}

Daun avokad, etanol 96\%, n-heksana, etil asetat, air, kontrol negatif yang digunakan adalah CMC, kontrol positif Captopril 25mg, pakan tukus BR1, bahan penginduksi Nacl dan Presnison. Klorofom, Metanol.

\section{Hewan Uji}

Penelitian ini menggunakan hewan uji tikus (Galur wistar) total hewan uji sebanyak 45 ekor, hewan uji dikelompokkan menjadi 9 dengan jumlah masing-masing kelompok sebanyak 5 hewan uji.

\section{Proses Pengeringan}

Daun alpukat diambil dari Kecamatan Pringsurat, Kabupaten Tawangmangu, Semarang Jawa Tengah, setelah itu disortasi, dicuci dengan air mengalir hingga bersih kemudian ditimbang.

Selanjutnya daun avokad yang telah ditimbang dipotong menjadi dua bagian hal ini berfungsi agar mudah proses pengeringannya kemudian siapkan tempat pengering atau oven dengan suhu $40^{\circ} \mathrm{C}$ diamkan sampai daun benar-benar mengering dan siap untuk dihaluskan yang berfungsi agar mempermudah proses penggilingan atau penyerbukan daun avokad (Elisa et al., 2020).

\section{Persiapan Simplisia}

Setelah daun avokad mengering dilanjutkan dengan proses penyerbukan simplisia kering daun avokad, dengan cara dihaluskan dengan alat penggiling atau penghalus simplisia.

Simplisia halus kemudian diayak dengan ayakan nomor 40 dan nomor 30, Diambil serbuk simplisia yang lolos ayakan nomor 30 dan tidak lolos ayakan nomor 40 kemudian disimpan dalam wadah tertutup, kering, tidak lembab (Elisa et al., 2020).

\section{Pembuatan Ekstrak Etanol}

Serbuk simplisia daun avokad yang sudah halus selanjutnya ditimbang menggunakan alat neraca kasar yakni sebanyak 558,4 g yang telah didapat dari hasil proses penyerbukan dan penyaringan.

Proses ekstraksi menggunakan pelarut etanol $96 \%$ yakni dengan perbandingan 1:10 (serbuk 558,4g : etanol 96\%) maserasi selama $3 \times 24$ jam dengan sesekali pengadukan jika sudah selesai maka dilanjut dengan penyaringan.

Maserat diambil menggunakan kertas saring whatman. Maserat ditampung dan ampas dipisahkan, setelah didapat hasil hitunglah rendemennya (Purwidyaningrum et al., 2017a). Proses tersebut dilakukan di Laboratorium Kimia Sekolah Tinggi Ilmu Farmasi Yayasan Pharmasi Semarang.

\section{Pembuatan Fraksi Air, Etil Asetat, n-Heksana}

Fraksinasi dengan metode ekstraksi cair-cair, Ekstrak etanol daun avokad sebanyak 100 gram dimasukkan dalam beaker glass tambahkan etanol sampai tercempur.

Masukkan pelarut air dan n-heksana dengan perbandingan (1:1) kedalam corong pisah, tambahkan dengan ekstrak etanol daun avokat yang sudah tercampur kemudian di kocok selama 1 menit dan didiamkan selama 10 menit. Fraksi air berada dibagian bawah diambil kemudian pekatkan dengan menggunakan waterbath pada suhu $40 \mathrm{oC}$ dan fraksi n-heksana dibagian atas dan pekatkan menggunakan rotary evaporator pada suhu $60 \mathrm{oC}$ proses ini dilakukan sebanyak 3 kali (Purwidyaningrum et al., 2017b).

Sebanyak100 gram ekstrak dimasukkan kedalam beaker glass dan tambahkan etanol hingga tercampur, masukkan pelarut air dan etil asetat dengan perbandingan (1:1) kedalam corong pisah ditambahkan dengan ekstrak etanol daun alpukat yang sudah tercampur kemudian dikocok selama 1 menit dan diamkan selama 10 menit. Fraksi air yang berada di bagian bawah diambil selanjutnya 
pekatkan menggunakan waterbath suhu $40 \mathrm{oC}$ dan fraksi etil asetat berada di bagian atas diambil dan dipekatkan menggunakan rotary evaporator pada suhu $60 \mathrm{oC}$ proses ini dilakukan sebanyak 3 kali (Purwidyaningrum et al., 2017a). Fraksi n-heksana, etil asetat dan air masing-masing di tempatkan di wadah terpisah dan diberi label nama masing-masing fraksi.

\section{Penetapan Susut Pengeringan}

Sebanyak 1 gram ekstrak etanol daun avokad diletakan pada lempeng alumunium foil kemudian letakan pada alat Moisture Analyzer selanjutnya panaskan pada suhu $105^{\circ} \mathrm{C}$ selama 15 menit, dilakukan $3 \mathrm{x}$ percobaan dihitung nilai rata-ratanya. Susut pengeringan dapat memenuhi syarat apabila $<10$ (Salamah \& Widyasari, 2015).

\section{Skrining Fitokimia}

Uji pendahuluan ekstrak dan fraksi-fraksi daun avokad yang dilakukan meliputi:

\section{Alkaloid}

Uji alkaloid yang dilakukan pertama timbang sebanyak 1 gram ekstrak kental dan fraksi-fraksi daun alpukat, sebanyak $1 \mathrm{ml} \mathrm{HCl}$ $2 \mathrm{~N}$ dan $9 \mathrm{ml}$ aquadest, dipanaskan di atas penangas air selama 2 menit setelah itu dinginkan dan saring, diambil filtrat beberapa tetes masukan ke dalam 3 tabung reaksi, ditambahkan 2 tetes pereaksi mayer dan terbentuk endapan putih/kuning, tambahkan 2 tetes pereaksi bouchardat sehingga terbentuk endapan coklat sampai hitam, tambahkan 2 tetes pereaksi dragendrof sehingga terbentuk endapan jingga sampai merah coklat, Bila sedikitnya 2 dari 3 pereaksi menghasilkan endapan yang sama maka positif mengandung alkaloid (Sentat \& Permatasari, 2017).

2. Flavonoid

Uji flavonoid yang dilakukan timbang sebanyak 1 gram ekstrak kental dan fraksifraksi daun alpukat, kemudian masukkan ke dalam tabung reaksi, tambahkan 2 tetes $\mathrm{HCl}$ pekat, serbuk Mg, dan 2 tetes amil alcohol, sehingga menghasilkan warna kuning, jingga, atau merah pada lapisan amil alkohol memberikan indikasi adanya flavonoid (Sentat \& Permatasari, 2017).

3. Uji Saponin

Uji saponin yang pertama timbang sebanyak 1 gram ekstrak kental dan fraksifraksi daun alpukat, kemudian masukkan ke dalam tabung reaksi, selanjutnya tambahkan air panas secukupnya, kemudian dikocok selama 15 menit dan tambahkan 2 tetes $\mathrm{HCl} 2$ $\mathrm{N}$, Bila terbentuk buih permanen selama kurang lebih 10 menit maka memberikan indikasi adanya saponin (Sentat \& Permatasari, 2017).

\section{Tanin}

Uji Tanin timbang sebanyak 1 gram ekstrak kental dan fraksi-fraksi daun alpukat, kemudian tambah $10 \mathrm{ml}$ air suling selanjutnya saring, Filtrat diencerkan dengan air suling sampai tidak berwarna, kemudian diambil 2 $\mathrm{mL}$ filtrat dan ditambahkan 1 sampai 2 tetes pereaksi $\mathrm{FeCl} 3$, bila terbentuk warna biru tua atau hijau kehitaman memberikan indikasi adanya tanin (Sentat \& Permatasari, 2017).

5. Uji Steroid dan Triterpenoid

Uji steroid dan triterpenoid yang dilakukan timbang sebanyak 1 gram ekstrak kental dan fraksi-fraksi daun alpukat, tambahkan pelarutnya kemudian diuapkan menggunakan cawan porselin. residu dilarutkan dengan $0,5 \mathrm{~mL}$ kloroform, kemudian ditambahkan $0,5 \mathrm{~mL}$ asam asetat anhidrat, tambahkan Asam sulfat pekat sebanyak $2 \mathrm{~mL}$ melalui dinding tabung, Terbentuk cincin kecoklatan atau violet pada perbatasan larutan menunjukkan adanya triterpenoid, sedangkan bila muncul cincin biru kehijauan menunjukkan adanya steroid (Manoranjan et al., 2018).

\section{Uji KLT Ekstrak dan Fraksi-fraksi}

\section{Ekstrak Daun Avokat}

Pembuatan fase gerak kloroform : metanol (1:9) dan penjenuhan, larutan baku kuersetin dan ekstrak kental daun avokat ditotolkan pada lempeng KLT kemudian spot dibawah lampu UV $254 \mathrm{~nm}$, Lempeng KLT dielusi hingga batas elusi, hasil spot diamati yang terpisah dengan sinar tampak, UV254, dan diberi penampak bercak uap moniak $25 \%$.

\section{Fraksi Air}

Pembuatan fase gerak kloroform : metanol (1:10) dan penjenuhan, baku kuersetin dan sampel fraksi air daun avokat ditotolkan pada lempeng KLT, Dilihat spot dibawah lampu UV $254 \mathrm{~nm}$, Lempeng KLT dielusi hingga batas elusi, Diamati spot yang terpisah dengan sinar tampak, UV254, dan diberi penampak bercak uap moniak $25 \%$.

\section{Fraksi n-heksana dan etil asetat}

Pembuatan fase gerak kloroform : metanol (4:6) dan penjenuhan, kemudian baku kuersetin dan etil asetat dan n-heksan daun 
avokat ditotolkan pada lempeng KLT, dilihat pada bagian spot dibawah lampu UV $254 \mathrm{~nm}$, lempeng KLT dielusi hingga batas elusi dan amati spot yang terpisah dengan sinar tampak, UV254, dan diberi penampak bercak uap moniak $25 \%$.

\section{Pembuatan stok prednisone $1,5 \mathrm{mg} / \mathrm{kgbb}$ tikus}

Dihitung dosis tikus terbesar dan konsentrasi larutan stok kemudian timbang beberapa tablet prednison dihitung reratanya ad halus, hitung serbuk yang akan digunakan, kemudian ditimbang dan hitunglah larutan stok sebenarnya, kembangkan CMC 0,5\%, disuspensikan prednison ke dalamnya. Masukan labu takar, tambahkan aquadest hingga tanda batas hingga homogen.

\section{Pembuatan Larutan Suspensi NaCl 2\%}

Dihitung $\mathrm{NaCl}$ yang dibutuhkan kemudian timbang, selanjutnya larutkan $\mathrm{NaCl}$ dalam aquadest, Dimasukan labu takar, tambahkan aquadest hingga tanda batas dan homogenkan.

\section{Uji Antihipertensi}

Penelitian aktivitas antihipertensi menggunakan 45 ekor tikus dan hewan uji dibagi menjadi 9 kelompok, dimana kelompok 1 (Kontrol Normal), kelompok II (Captopril 25mg), kelompok III ( $\mathrm{Na} \mathrm{CMC} 0.5 \%$ ), kelompok IV (E. 75mg), kelompok V (E. 150mg), kelompok VI (E. 250mg), kelompok VII (FA), kelompok VIII (FEA), kelompok IX (FH).

Pengujian pertama yaitu kelompok 1-6 dahulu kemudian diukur tekanan darah dengan menggunakan alat MrBP Blood Pressure Analizer Tail Caff pada hari ke-0 (T0) sebelum perlakuan. Pada T0 diberikan standart pakan BR1 dan diberi minum, Hari ke 1-7 (T1) diberikan prednisone dan $\mathrm{NaCl}$ sebagai induksi kemudian hari ke-7 diukur tekanan darahnya, kemudian pada hari ke 8-14 (T2) diberikan prednisone dan $\mathrm{NaCl}$ sebagai induksi kemudian hari ke-14 diukur tekanan darahnya dan pada hari ke 15-21 (T3) diberikan prednisone dan $\mathrm{NaCl}$ sebagai induksi kemudian hari ke-21 diukur tekanan darahnya. Hari ke 22-28 (T4) diberikan captopril $25 \mathrm{mg}$ dan dosis ekstrak $75 \mathrm{mg}$, $150 \mathrm{mg}, 250 \mathrm{mg} / \mathrm{KgBB}$ hari ke-28 diukur tekanan darahnya, selanjutnya dosis ekstrak terbaik dilanjutkan ke dosis fraksi air, etil asetat, $\mathrm{n}$-heksana dengan perlakuan yang sama (Purwidyaningrum et al., 2017a).

\section{HASIL DAN PEMBAHASAN}

Hasil uji pendahuluan determinasi tanaman menyatakan spesies tumbuhan merupakan tanaman Persea Americana Mill (Soemarie et al., 2016). Pengujian dilakukan di Laboratorium Stifar Yayasan Farmasi Semarang.

\section{Hasil uji skrinning fitokimia}

Uji skrinning fitokimia adalah untuk mengetahui senyawa-senyawa metabolit sekunder yang ada di dalam kandungan ekstrak dan fraksi tersebut. Dari hasil pengujian diketahui alkaloid, flavonoid, tannin, saponin, steroid dan triterpenoid yang dapat dilihat pada Tabel 1 (Sentat \& Permatasari, 2017).

Tabel 1. Hasil Skrinning Fitokimia Ekstrak dan Fraksi-Fraksi

\begin{tabular}{|c|c|c|c|c|}
\hline \multirow{2}{*}{$\begin{array}{c}\text { Senyawa } \\
\text { kimia }\end{array}$} & \multicolumn{4}{|c|}{ Hasil } \\
\hline & $\begin{array}{l}\text { Eks- } \\
\text { trak }\end{array}$ & $\begin{array}{l}\text { Fraksi } \\
\text { Air }\end{array}$ & $\begin{array}{l}\text { Fraksi } \\
\text { n-Hkn }\end{array}$ & $\begin{array}{c}\text { Fraksi } \\
\text { EA }\end{array}$ \\
\hline \multicolumn{5}{|l|}{ Alkaloid } \\
\hline Mayer & + & + & - & - \\
\hline Dragendroff & + & + & - & - \\
\hline Bouchardat & + & + & - & - \\
\hline Flavonoid & + & + & + & + \\
\hline Tannin & + & - & + & - \\
\hline Saponin & + & + & + & + \\
\hline $\begin{array}{l}\text { Steroid dan } \\
\text { triterpenoid }\end{array}$ & + & + & + & + \\
\hline \multicolumn{5}{|c|}{ (+) Positif Menunjukkan hasil positif } \\
\hline \multicolumn{5}{|c|}{ (-) Negatif menunjukkan hasil negatif } \\
\hline \multicolumn{5}{|c|}{ Uji KLT (Kromatografi Lapis Tipis) } \\
\hline
\end{tabular}

Tabel 2. Hasil Uji KLT Ekstrak dan FraksiFraksi dengan standar kuersetin

\begin{tabular}{cc}
\hline Sampel & Nilai Rf Kuersetin \\
\hline Ekstrak & 0.75 \\
Fraksi Air & 0.82 \\
Fraksi n-Heksan & 0.93 \\
Fraksi Etil Asetat & 0.81 \\
\hline
\end{tabular}

Tahap pengujian dengan menggunakan spektrofotometer visibel yang berfungsi menentukan waktu oprasional OP (Operating time) pada saat pengukuran penyerap sinar dalam keadaan stabil dengan membuktikan aktivitas hipertensi bereaksi secara optimal antara senyawa dan standar baku kuersetin diberi penampak bercak uap moniak $25 \%$ (Anggorowati et al., 2016). 


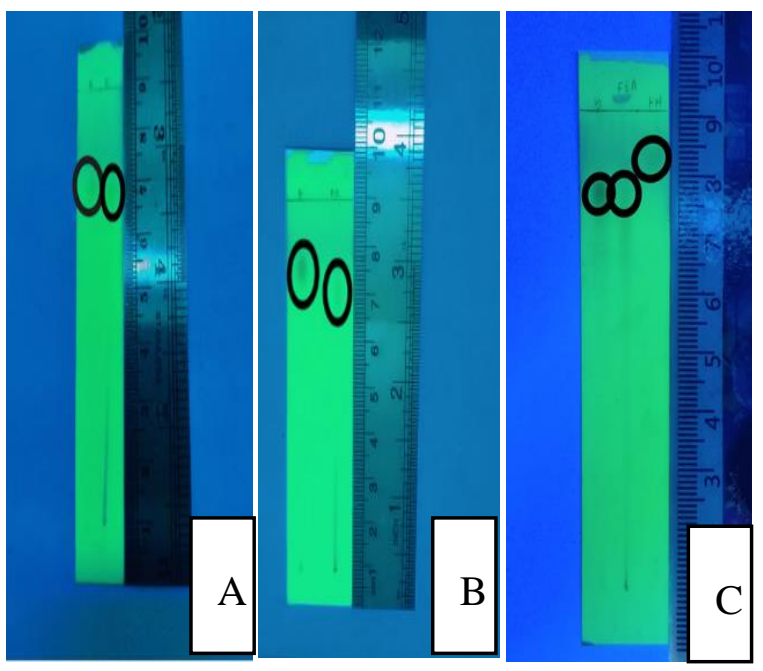

Gambar 1. Hasil KLT pada UV254

Keterangan:

A Ekstrak

B Fraksi Air

C Fraksi n-Heksana, Etil Asetat

Tabel 2 menunjukkan bahwa kandungan aktivitas antihipertensi dari ekstrak daun alpukat tidak jauh antara sampel uji, dimana hal ini dapat dibuktikan dengan nilai Rf yang dihasilkan setelah percobaan KTL dengan penyinaran UV 254, ekstrak daun alpukat dengan menggunakan baku kuersetin yang dihasilkan $\operatorname{Rf} 0,75$, fraksi air 0,82 , nheksana 0,93 , etil asetat 0,82 dari hasil tersebut dapat dibuktikan bahwa penurunan aktivitas antihipertensi tidak terlalu jauh antara kelompok uji. Berdasarkan penelitian sebelumnya pada uji antioksidan dengan menggunakan baku kuersetin sama halnya tidak terlalu jauh dalam memberikan efek antara kelompok uji (Anggorowati et al., 2016).

Tabel 3. Susut Pengeringan

\begin{tabular}{ccc}
\hline No & $\begin{array}{c}\text { Penimba- } \\
\text { ngan }(\mathbf{g})\end{array}$ & $\begin{array}{c}\text { Susut penge- } \\
\text { ringan }(\boldsymbol{\%})\end{array}$ \\
\hline 1 & 1,0 & 7,73 \\
2 & 1,0 & 8,89 \\
3 & 1,0 & 8,96 \\
\hline & Rata-rata & $8,53 \pm 0,69$ \\
\hline
\end{tabular}

Tabel 3 menunjukkan susut pengeringan dari ekstrak daun avokad yang dilakukan sebanyak 3 kali perakuan dengan pemanasan suhu $105^{\circ} \mathrm{C}$ selama 15 menit diperoleh ratarata $8,53 \%$ dengan nilai $\mathrm{SD} 0,69$, hal ini menunjukkan bahwa ekstrak daun avokad terdapat air dan zat-zat volatile 8,53\% dengan kandungan kelembaban sebagai syarat kurang dari 10\% (Indriyanti et al., 2017).

Tabel 4. Tekanan darah ekstrak sistolik

\begin{tabular}{ccccccc}
\hline \multirow{2}{*}{ Kelompok } & \multicolumn{3}{c}{ AUC TD Sistolik (mmHg.Hari) } & & Total & Persentase \\
\cline { 2 - 5 } & T0-T1 & T1-T2 & T2-T3 & T3-T4 & AUC & Penurunan \\
\hline Normal & $749 \pm 34 \mathrm{ab}$ & $758 \pm 20 \mathrm{ab}$ & $759 \pm 37 \mathrm{ab}$ & $794 \pm 53 \mathrm{ab}$ & $3060 \pm 108$ & - \\
Positif & $883 \pm 31 \mathrm{a}$ & $1023 \pm 9 \mathrm{a}$ & $1044 \pm 18 \mathrm{a}$ & $951 \pm 12 \mathrm{a}$ & $3901 \pm 22$ & $5,45 \pm 27,23$ \\
Negatif & $949 \pm 17 \mathrm{c}$ & $1060 \pm 7 \mathrm{c}$ & $1060 \pm 23 \mathrm{c}$ & $1057 \pm 14 \mathrm{c}$ & $4125 \pm 29$ & - \\
E 75mg/kgbb & $816 \pm 216 \mathrm{c}$ & $1030 \pm 36 \mathrm{c}$ & $1080 \pm 25 \mathrm{c}$ & $1068 \pm 17 \mathrm{c}$ & $3994 \pm 164$ & $3,18 \pm 3,72$ \\
E 150mg/kgbb & $917 \pm 23 \mathrm{c}$ & $1032 \pm 23 \mathrm{c}$ & $1086 \pm 11 \mathrm{c}$ & $1037 \pm 43 \mathrm{c}$ & $4072 \pm 39$ & $1,29 \pm 1,03$ \\
E 250 mg/kgbb & $909 \pm 36 \mathrm{ac}$ & $1017 \pm 25 \mathrm{ac}$ & $1029 \pm 21 \mathrm{ac}$ & $928 \pm 30 \mathrm{ac}$ & $3883 \pm 11$ & $5,87 \pm 0,63$ \\
\hline
\end{tabular}

Keterangan: abc $=$ Hasil total AUC perbedaan makna penurunan tekanan darah

a. Berbeda makna terhadap kelompok negatif $<0,05$

b. Berbeda makna terhadap kelompok terapi $<0,05$

c. Berbeda makna terhadap kelompok normal $<0,05$

Tabel 5. Tekanan darah ekstrak diastolik

\begin{tabular}{ccccccc}
\hline \multirow{2}{*}{ Kelompok } & \multicolumn{4}{c}{ Total TD Diastolik (mmHg.Hari) } & \multirow{2}{*}{ Total AUC } & \multicolumn{2}{c}{$\begin{array}{c}\text { Persentase } \\
\text { Penurunan }\end{array}$} \\
\cline { 2 - 5 } & T0-T1 & T1-T2 & T2-T3 & T3-T4 & & - \\
Normal & $665 \pm 23 \mathrm{ab}$ & $718 \pm 44 \mathrm{ab}$ & $703 \pm 55 \mathrm{ab}$ & $610 \pm 107 \mathrm{ab}$ & $2696 \pm 107$ & $9.16 \pm 3.44$ \\
Positif & $679 \pm 32 \mathrm{a}$ & $784 \pm 47 \mathrm{a}$ & $870 \pm 41 \mathrm{a}$ & $759 \pm 35 \mathrm{a}$ & $3091 \pm 81$ & - \\
Negatif & $38 \pm 56 \mathrm{c}$ & $916 \pm 46 \mathrm{c}$ & $879 \pm 51 \mathrm{c}$ & $828 \pm 25 \mathrm{c}$ & $3407 \pm 142$ & $-0.92 \pm 3.03$ \\
E 75mg/kgbb & $773 \pm 51 \mathrm{c}$ & $920 \pm 24 \mathrm{c}$ & $903 \pm 15 \mathrm{c}$ & $840 \pm 07 \mathrm{c}$ & $3435 \pm 58$ & $-3.05 \pm 6.93$ \\
E 150mg/kgbb & $777 \pm 55 \mathrm{c}$ & $859 \pm 52 \mathrm{c}$ & $946 \pm 44 \mathrm{c}$ & $878 \pm 16 \mathrm{c}$ & $3503 \pm 112$ & $-10.96 \pm 6.62$ \\
E 250mg/kgbb & $777 \pm 55 \mathrm{ac}$ & $849 \pm 30 \mathrm{ac}$ & $697 \pm 315 \mathrm{ac}$ & $714 \pm 66 \mathrm{ac}$ & $3037 \pm 289$ & 10.9 \\
\hline
\end{tabular}

Keterangan: abc $=$ Hasil total AUC perbedaan makna penurunan tekanan darah

a. Berbeda makna terhadap kelompok negatif $<0,05$
b. Berbeda makna terhadap kelompok terapi $<0,05$
c. Berbeda makna terhadap kelompok normal $<0,05$ 
Tabel 6. Tekanan darah fraksi sistolik

\begin{tabular}{ccccccc}
\hline \multirow{2}{*}{ Kelompok } & \multicolumn{3}{c}{ Total TD Sistolik (mmHg.Hari) } & \multirow{2}{*}{ Total AUC } & Persentase \\
\cline { 2 - 5 } & T0-T1 & T1-T2 & T2-T3 & T3-T4 & & Penurunan \\
\hline Fraksi Air 25mg/ml & $896 \pm 22 \mathrm{c}$ & $1009 \pm 22 \mathrm{c}$ & $1086 \pm 23 \mathrm{c}$ & $1060 \pm 22 \mathrm{c}$ & $4050 \pm 66$ & $1.82 \pm 1.27$ \\
Fraksi EA 25mg/ml & $871 \pm 26 \mathrm{ac}$ & $979 \pm 16 \mathrm{c}$ & $1065 \pm 18 \mathrm{ac}$ & $975 \pm 20 \mathrm{ac}$ & $3890 \pm 43$ & $5.71 \pm 0.63$ \\
Fraksi n-Hkn 25mg/ml & $894 \pm 21 \mathrm{c}$ & $1027 \pm 15 \mathrm{c}$ & $1087 \pm 16 \mathrm{c}$ & $1071 \pm 25 \mathrm{c}$ & $4078 \pm 55$ & $1.14 \pm 0.99$ \\
\hline
\end{tabular}

Keterangan: $a b c=$ Hasil total AUC perbedaan makna penurunan tekanan darah

a. Berbeda makna terhadap kelompok negatif $<0,05$

b. Berbeda makna terhadap kelompok terapi $<0,05$

c. Berbeda makna terhadap kelompok normal $<0,05$

Tabel 7. Tekanan darah fraksi diastolik

\begin{tabular}{|c|c|c|c|c|c|c|}
\hline \multirow[t]{2}{*}{ Kelompok } & \multicolumn{4}{|c|}{ Total TD Diastolik (mmHg.Hari) } & \multirow[t]{2}{*}{ Total AUC } & \multirow{2}{*}{$\begin{array}{l}\text { Persentase } \\
\text { penurunan }\end{array}$} \\
\hline & T0-T1 & T1-T2 & T2-T3 & T3-T4 & & \\
\hline & $703 \pm 49 c$ & $829=$ & 8 & & & \\
\hline Fraksi EA 25mg/ml & $56 \pm 41 \mathrm{ac}$ & $709 \pm 18 \mathrm{ac}$ & $778 \pm 12 \mathrm{ac}$ & $753 \pm 09 \mathrm{ac}$ & $2907 \pm 73$ & $14.53 \pm 4.88$ \\
\hline Fraksi n-Hkn $25 \mathrm{mg} / \mathrm{ml}$ & $693 \pm 61 c$ & $843 \pm 37 c$ & $878 \pm 31 \mathrm{c}$ & $814 \pm 12 c$ & $3227 \pm 78$ & $5.23 \pm 1.90$ \\
\hline
\end{tabular}

Keterangan: $a b c=$ Hasil total AUC perbedaan makna penurunan tekanan darah

a. Berbeda makna terhadap kelompok negatif $<0,05$

b. Berbeda makna terhadap kelompok terapi $<0,05$

c. Berbeda makna terhadap kelompok normal $<0,05$

Hipertensi terjadi dikarenakan kondisi arterosklerosis pada arteri terutama yang mengalir pada aorta jantung. Bagian arteri terjadi pengerasan dan kekakuan sehingga aorta dan arteri kehilangan kekuatan dalam pergerakan. Dinding arteri yang sekarang tidak elastis tidak dapat lagi mengeluarkan darah dari jantung ke dalam aliran darah. Peningkatan tekanan darah yang terjadi dapat menimbulkan beberapa gejala pada organ target yang terlibat seperti stroke, otak, penyakit jantung koroner untuk pembuluh darah jantung dan otot jantung (Isnaini \& Fulanah, 2019). Peran dari parameter sistolik adalah keadaan jantung mengalami fase kontraksi dan diastolik adalah keadaan jantung mengalami relaksasi (Elisa et al., 2020).

$\mathrm{NaCl}$ dan prednisone digunakan sebagai penginduksi dalam penelitian ini. Dimana $\mathrm{NaCl}$ dan prednisone memiliki mekanisme kerja dalam meningkatkan tekanan darah dan ada beberapa faktor antara lain adanya peningkatan asupan garam di dalam tubuh tinggi sehingga volume cairan ekstrasel terjadi peningkatan hal tersebut yang dapat menyebabkan terjadinya penyakit hipertensi (Rauf et al., 2018).

\section{Aktivitas Antihipertensi}

Obat golongan kortikosteroid meningkatkan retensi natrium dan air melalui organ ginjal. Pada kasus peningkatan tekanan darah sebagai efek terapi obat dengan dosis tinggi antara lain $20 \%$, obat kortikosteroid akan memberikan efek meningkatkan tekanan darah tergantung lamanya waktu pemberiaan atau penggunakan obat tersebut, hal ini terjadi pada pasien jika menerima obat kortikosteroid dengan dosis ekuivalen $>20 \mathrm{mg} /$ hari (Rauf et al., 2018).

Hasil penelitian pada Tabel 4 dan Tabel 5 dengan parameter sistolik dan diastolik menjelaskan kelompok kontrol normal berbeda makna dengan kelompok terapi dan kelompok negatif dengan nilai sig $<0.05$. Sedangkan kelompok terapi kontrol positif (captopril) persentasi penurunan sistolik $(5,45 \pm 27,23)$, diastolik $(9,16 \pm 3,44)$ berbeda makna dengan kelompok kontrol negatif dengan nilai sig <0.05. kelompok ekstrak dosis $75 \mathrm{mg} / \mathrm{kgbb}$ persentase penurunan sistolik $(3,18 \pm 3,72)$, diastolik $(-0.92 \pm 3,03)$ dan $150 \mathrm{mg} / \mathrm{kgbb}$ persentase penurunan sistolik $(1,29 \pm 1,0)$, diastolik $(-3,05 \pm 6,93)$ berbeda makna dengan kelompok kontrol normal dengan nilai sig $<0.05$. Kelompok ekstrak dosis $250 \mathrm{mg} / \mathrm{kgbb}$ persentase penurunan sistolik $(5,87 \pm 0,63)$, diastolik $(10,96 \pm 6,62)$ berbeda makna dengan kelompok kontrol normal dan negatif dengan nilai sig $<0.05$.

Hasil penelitian uji fraksi air, etil asetat, n-heksana pada Tabel 6 dan Tabel 7 dengan parameter sistolik dan diastolik menunjukkan fraksi air persentase penurunan sistolik $(1,82 \pm 1,27)$, diastolik $(4,83 \pm 4,95)$ kemudian pada fraksi n-heksana persentase penurunan sistolik $(1,14 \pm 0.99)$, diastolik $(5,23 \pm 1,90)$ 
berbeda makna dengan kelompok kontrol normal dengan nilai sig $<0.05$, sedangakan pada fraksi etil asetat persentase penurunan sistolik $(5,71 \pm 0,63)$, diastolik $(14,53 \pm 4,88)$ berbeda makna dengan kelompok normal dan negatif dengan nilai sig $<0,05$. Sehingga hasil penelitian penelitian sesuai dengan literature sebelumnya. Nilai normal tenakan darah hewan uji tikus adalah 180/145 $\mathrm{mmHg}$ dapat dilihat pada tabel Laurence et al. (1964), pada manusia nilai normal tekanan darah berdasarkan JNC VIII 120/80 mmHg (Wells et al., 2009).

Penelitian model hipertensi dengan pemberian induksi $\mathrm{NaCl}$ memberikan hasil perbedaan makna dimana dapat disesuaikan dengan literatur yang sebelumnya bahwa $\mathrm{NaCl}$ di dalam tubuh jika dalam kondisi berlebih maka dapat menyebabkan asupan garam di dalam tubuh tinggi sehingga volume cairan ekstrasel terjadi peningkatan sedangakan obat-obat golongan kortikostroid seperti prednisone jika di gunakan dalam waktu yang lama akan meningkatkan retensi natrium dan air melalui organ ginjal (Rauf $e t$ al., 2018).

Hasil penelitian ini sesuai dengan penelitian (Setyawan, 2018) yang menyatakan bahwa daun avokad memiliki aktivitas sebagai hipertensi diuretik, ekstrak daun avokad diketahui dapat menurunkan tekanan darah pada penderita hipertensi secara signifikan, menurunkan kadar glukosa darah serta dapat menurunkan kadar ureum dan kreatinin pada ginjal (Triani et al., 2016). Penelitian oleh Ojewole menyatakan daun avokad berkontribusi terhadap penurunan tekanan darah melalui efek vasorelaksan, kandungan daun avokad memiliki kandungan kalium yang tinggi, kadar kalium diperlukan untuk keseimbangan elektrolit, mengontrol tekanan darah, sehingga hal ini dapat menjadi dasar dalam menurunkan tekanan darah (Setyawan, 2018).

Menurut penelitian senyawa kimia yang terlibat yaitu flavonoid. Peran dari flavonoid memiliki mekanisme menurunkan tekanan darah dengan cara melancarkan peredaran darah dan mencegah terjadinya penyumbatan pada pembuluh darah sehingga darah dapat mengalir dengan normal. Flavonoid termasuk dalam golongan fenol yang telah beredar bebas di alam (Nur et al., 2019).

Flavonoid memiliki fungsi dalam memperbaiki endotel, kemudian lavonoid akan mempengaruhi kerja dari Angiotensin Converting Enzym (ACE) yang dapat perberan dalam vasodilatasi sehingga tahanan resistensi perifer menurun dan dapat menurunkan tekanan darah (Nur et al., 2019) Pada literature sebelumnya menjelaskan ekstrak dari daun avokad dapat menurunkan tekanan darah dengan dosis $100 \mathrm{mg} / \mathrm{kgbb}$ dan senyawa yang berperan berdasarkan hasil uji skrining fitokimia adalah flavonoid (Anggorowati et al., 2016).

\section{KESIMPULAN}

Ekstrak dan fraksi-fraksi daun avokad (Persea americana Mill) memiliki efek dalam menurunkan tekanan darah pada dosis ekstrak yang terbaik adalah $250 \mathrm{mg} / \mathrm{kgbb}$ dengan hasil

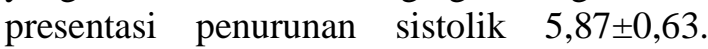
Diastolik $10.96 \pm 6.62$ sedangakan pada fraksi terbaik adalah etil asetat dengan presentai penurunan sistolik $5.71 \pm 0.63$ dan diastolik $14.53 \pm 4.88$. Senyawa yang berperan dalam penurunkan tekanan darah adalah flavonoid berdasarkan uji skrining fitokimia dan uji KLT.

\section{UCAPAN TERIMA KASIH}

Ucapan Terima kasih kepada Direktorat Riset dan Pengabdian Masyarakat. Direktorat Jenderal Penguatan Riset dan Pengembangan Kemenristekdikti yang telah memberikan fasilitas pendanaan Hibah Penelitian Dosen Pemula (PDP) dengan perjanjian kontrak Nomor: $\quad$ 067/E4.1/AK.04.PT/2021. Selanjutnya terima kasih pada LPPM Stifar Yayasan Pharmasi Semarang yang telah membantu dalam melancarkan penelitian.

\section{DAFTAR PUSTAKA}

Anggorowati, D., Priandini, G. \& Thufail. 2016. Potensi daun alpukat (persea americana miller) sebagai minuman teh herbal yang kaya antioksidan. Industri Inovatif, 6(1): 1-7.

Barnes, P.M., Bloom, B., \& Nahin, R.L. 2008. Complementary and alternative medicine use among adults and children: United States, 2007. National Health Statistics Reports, 12. DEPKES. 2006. Untuk Penyakit Hipertensi. Buku, BUKU, 1-37. 
DINKES Sulut. 2016. Renstra dinas kesehatan prov sulut 2016-2021. 1-125.

Elisa, N., Xaverius, F. \& Wibowo, S. 2020. Hypertension Profile of Angiotensin Receptor Blocker From Matoa Leaves Extract ( Pometia Pinnata J.R. Foster \& $\mathrm{G}$. Foster ) In Angiotensin II InducedMale Rat. STRADA Jurnal Ilmiah Kesehatan, 9(2):1830-1836. https://doi. org/10.30994/sjik.v9i2.595.

Indriyanti, E., Purwaningsih, Y. \& Wigati, D. 2017. Skrining Fitokimia dan Standarisasi ekstrak kulit buah labu kuning (Cucurbita moschata). Jurnal Ilmiah Cendekia Eksakta, 3(2): 20-25.

Isnaini, N. \& Fulanah, U. 2019. Penurunan tekanan darah dengan simplisia daun alpokat Decreasing blood pressure with avoid simplicia leaves. Journal of Health Studies, 3(1):44-52. https://doi.org/10.31101/jhes.839.

Kemenkes RI. 2014. Situasi kesehatan jantung. Pusat Data Dan Informasi Kementerian Kesehatan RI, 3. https://doi.org/10.1017/CBO97811074 15324.004.

Mancia, G., Fagard, R., Narkiewicz, K., Redon, J., Zanchetti, A., Böhm, M., Christiaens, T., Cifkova, R., De Backer, G., Dominiczak, A., Galderisi, M., Grobbee, D.E., Jaarsma, T., Kirchhof, P., Kjeldsen, S.E., Laurent, S., Manolis, A.J., Nilsson, P.M., Ruilope, L.M. \& Wood, D.A. 2013. 2013 ESH/ESC guidelines for the management of arterial hypertension: The Task Force for the management of arterial hypertension of the European Society of Hypertension (ESH) and of the European Society of Cardiology (ESC). European Heart Journal, 34(28): 21592219. https://doi.org/10.1093/eurheartj/ eht151.

Manoranjan, T., Thangarajah, R. \& Thavaranjit, A.C. 2018. Antifungal Activity and Qualitative Phytochemical Analysis of Some Medicinal Plants in Jaffna (Sri Lanka). International Journal of Organic Chemistry, 8(4): 335-340. https://doi.org/10.4236/ijoc. 2018.84025 .
Mardiyaningsih, A. \& Ismiyati, N. (2014). Cytotoxic Activity Of Ethanolic Extract Of Persea Americana Mill . Leaves On Hela Cervical Cancer Cell. Traditional Medicine Journal, 19(1): 24-28.

Nur, F., Sami, F.J., Awaluddin, A. \& Afsari, M.I.A. 2019. Korelasi antara kadar total flavonoid dan fenolik dari ekstrak dan fraksi daun jati putih (Gmelina arborea Roxb.) terhadap aktivitas antioksidan. Jurnal Farmasi Galenika, 5(1):33-42. Https://doi.org/10.22487/ j24428744.2019.v5i1.12034.

Purwidyaningrum, I., Sukandar, E.Y. \& Fidrianny, I. 2017a. Antihypertensive activity of extract and fractions of matoa (Pometia Pinnata J. R \& G forts) leaves. Asian Journal of Pharmaceutical and Clinical Research, 10(3):323-328. ttps://doi.org/10.22159 /ajpcr.2017.v10i3.16221.

Purwidyaningrum, I., Sukandar, E.Y. \& Fidrianny, I. 2017b. Diuretic activity of matoa leaves extracts and fractions (Pometia pinnata J.R. Forster \& J.G Forster) and its influence on potassium and sodium levels. Asian Journal of Pharmaceutical and Clinical Research, 10:31-34. https://doi.org/10.22159 /ajpcr.2017.v10s2.19481.

Rauf, A., Ningsi, S. \& Suhaidarwati, F. 2018. Uji Efek Ekstrak Etanol Bawang Dayak (Eleutherine Americana Merr.) Sebagai Antihipertensi Pada Tikus Jantan (Rattus norvegicus). Jurnal Farmasi FakultasKedokteran Dan Ilmu Kesehatan, 6(1):55-65.

Salamah, N. \& Widyasari, E. 2015. Aktivitas antioksidan ekstrak metanol daun kelengkeng (Euphoria longan (L) Steud.) dengan metode penangkapan radikal 2,2'-Difenil-1-Pikrilhidrazil. Pharmaciana, 5(1):25-34.

Sentat, T. \& Permatasari, R. 2017. Uji aktivitas ekstrak etanol daun alpukat (Persea americana Mill.) terhadap penyembuhan luka bakar pada punggung mencit putih jantan (Mus musculus). Jurnal Ilmiah Manuntung, 1(2):100-106. https://doi.org/10.51352 /jim.v1i2.20. 
Setyawan, A.B. 2018. Pengaruh Rebusan Daun Alpukat Terhadap Penurunan Tekanan Darah Pada Penderita Hipertensi. Jurnal Ilmu Kesehatan, 6(1):1-9.

Soemarie, Y.B., Astuti, T. \& Rochmah, V. 2016. Formulasi sediaan salep ekstrak daun alpukat (Persea americana Mill.) sebagai antiacne. Jurnal Ilmiah Manuntung, 2(2):224-232.

Wells, B.G., Dipiro, J.T., Dipiro, C.V. \& Schwinghammer, T.L. 2009. Pharmacotherapy Handbook $7^{\text {th }}$ Edition. McGraw Hill, New York. 